\title{
Chemical Composition of Bottom Sediments in Small Mountain Rivers (Altai, the Russian Federation)
}

\author{
Oleg Savichev ${ }^{1,2}$, Irina SMatveenko ${ }^{1}$, and Vladimir Paromov ${ }^{2}$ \\ ${ }^{1}$ Tomsk Polytechnic University, Institute of Natural Resources, 634050, Lenin Avenue, 30,Tomsk, \\ Russia \\ ${ }^{2}$ Tomsk State University, 634050, Lenin Avenue, 36,Tomsk, Russia
}

\begin{abstract}
The article deals with the chemical composition of bottom sediments in the small mountain rivers Aktru, Tyute, and Uznezya (Altai, Russia). It is established that as compared to small and middle plain rivers in Taiga zone, Siberia bottom sediments of the Aktru River contain less amount of $\mathrm{K}, \mathrm{Na}, \mathrm{V}, \mathrm{Cr}, \mathrm{Mn}, \mathrm{Ni}, \mathrm{Al}, \mathrm{Si}, \mathrm{Ti}, \mathrm{Sr}$, approximately the same $\mathrm{Fe}, \mathrm{Co}, \mathrm{Cu}, \mathrm{Zn}, \mathrm{Pb}$ and more - $\mathrm{As}, \mathrm{Ca}, \mathrm{Mg}$. It is suggested that there is a sharp increase of relative $\mathrm{Al}, \mathrm{Na}, \mathrm{K}$ and $\mathrm{Si}$ shares from the upland to lowland due to both weathering products accumulation of primary alumosilicates in bottom sediments and export of $\mathrm{Ca}$ and $\mathrm{Mg}$ from them when dissolving carbonate minerals. Composition transformations of bottom sediments is non-linear and considerably depends on composition of underlying and water-bearing rocks and water exchange intensity that manages time, conditions, and stages of interactions in "water - organic matter - rock" system.
\end{abstract}

\section{Introduction}

Humic Rivers consisting of surface water and lands covered with it within the shore line with bottom sediments (solid particles) formed as a result of different physical, chemical, and biological processes in a water body and its watershed are a boundary layer between rivers and subsurface, their chemical composition being one of the most essential factors for evaluating general state of water ecosystems and indicator of natural-anthropogenic changes in climate and environment $[1,2]$. Therefore, the adequate study in ecological and geochemical conditions of water bodies should include investigation of chemical composition of not only water, but also bottom sediments. In this connection, in the recent decades the study in bottom sediments (hereinafter referred to as river sediments) in vicinity of residential areas and industrial centers is being given focused attention in many parts of the world, particularly in the high anthropogenic-risk areas [2, 3]. Research of rivers not exposed to direct impact is of considerable interest. It is explained by the fact that the results of such a research would contribute to determining or specifying the conditions of natural geochemical anomalies development as an important indicator of hydrogenic mineral deposits. Of particular interest is the study in chemical composition of mountain river bottom sediments with abrupt height and slopes, which the elevated element concentrations are often associated with. Besides, the data on river conditions with minimal anthropogenic impact may and should be used in evaluating background geochemical indicators.

The arguments presented above serve as a basis for research in chemical composition of bottom sediments of small rivers Aktru, Tyute, and Uznezya in Gorny Altai (Russia). The Uznezya River is a right tributary of the Katun River, its length $-25 \mathrm{~km}$, watershed line head - $1459 \mathrm{~m}$, there is no ice in the basin. The Aktru River (can also termed as "Ak- 
Turu") is an element of "Aktru - Chuya - Katun - Ob" drainage network, a left tributary of the Chuya River. The river length is $25 \mathrm{~km}$, catchment area $-161.4 \mathrm{~km}^{2}$, source altitude $2750 \mathrm{~m}$, the maximum elevation $-4044 \mathrm{~m}$. Within the catchment area there are seven glaciers of total area $16.7 \mathrm{~km}^{2}$. The largest glaciers among those of the catchment involved are mountain-valley glaciers of the Left, Right, and Small Aktru. The major part of water flow of the Aktru River forms in the upstream within $20-25 \mathrm{~km}$ from the mouth. The Tyute River is also the left tributary of the Chuya River, its length $-33.8 \mathrm{~km}$, catchment area $163.5 \mathrm{~km}^{2}$, the maximum elevation $-3556 \mathrm{~m}$; in catchment area of the Tyute River there are 4 glaciers of total area $3.0 \mathrm{~km}^{2}[4,5]$.

The choice of the water bodies mentioned above is conditioned by the following reasons: 1) the Aktru, Uznezya, Tyute Rivers are typical water streams of Gorny Altai with minimal economic impacts on the river ecosystems; 2) the data on the Aktru and Tyute Rivers can be used to study other mountain-glacier basins of the Southern Siberia, the data on the Uznezya River - small mountain water streams without glacier inflow; 3) in 19621994 hydrological monitoring was performed at the Aktru River, but at present the researchers of Tomsk State University (TSU) and Tomsk Polytechnic University (TPU) are performing observation of glacier dynamics and sporadic hydrometeorological and hydrochemical analyses [4-7]. The main goal of the research is to estimate the average chemical composition of bottom sediment water in small mountain rivers with minimal anthropogenic impact and to reveal the trends in its length changes as well as relations with water chemical composition and mineral composition of bottom sediments. These facts define the research structure.

\section{Materials and Methods}

The research suggests field and laboratory work, analysis of field and laboratory data.

1. The fieldwork is carried out in term of the requirements $[1,3]$ and includes sampling of river water and bottom sediments: the Aktru River - in July of 2013; the Tyute River in July of 2014; the Uznezya River - in August of 2013. Bottom sediments are sampled in low flow zones $0.2-1.0 \mathrm{~m}$ from the water edge from the layer $0.2 \mathrm{~m}$ using plastic sampler. The river waters are sampled at the same point (before bottom sediment sampling) from the layer $0.3-0.5 \mathrm{~m}$ from the surface. Water discharge is measured in the Aktru and Tyute Rivers additionally (using current meter GR-21M). The layout of sampling points is given in $[7,8]$.

2. The laboratory work is performed in TPU and TSU, including analysis of: 2.1) composition of river water - in TPU under supervision of N.V. Guseva, A.A. Khvashchevskaya and V.A. Tarbokov using the following methods: $\mathrm{pH}$ - potentiometric; $\mathrm{SO}_{4}{ }^{2-}$, - turbidimetric; $\mathrm{Ca}^{2+}, \mathrm{Mg}^{2+}, \mathrm{HCO}_{3}{ }^{-}, \mathrm{Cl}^{-}$, dichromate oxidizability (DO) - titrimetric; nitrogen compounds, phosphates, $\mathrm{Si}$ - photometric; $\mathrm{Al}$ - fluorometric; $\mathrm{Na}^{+}, \mathrm{K}^{+}, \mathrm{Fe}-$ atomic absorption; $\mathrm{Zn}, \mathrm{Pb}, \mathrm{Cu}$ - stripping voltammetry; Li, Ti, V, Cr, Mn, Co, Ni, As, Sr, Cd, Sn, $\mathrm{Ba}$ - atomic emission spectroscopy with inductively coupled plasma; 2.2) composition of bottom sediments with the particle diameter of up to $1 \mathrm{~mm}$ - in TPU as well as using the following methods: $\mathrm{pH}$ of water extract - potentiometric; concentrations of $\mathrm{Ca}^{2+}, \mathrm{Mg}^{2+}$, $\mathrm{HCO}_{3}^{-}, \mathrm{Cl}^{-}$, carbon of water-soluble organic substances $\mathrm{C}_{\text {org }}$ in water extract photometric; $\mathrm{SO}_{4}{ }^{2-}$ in water extract - turbidimetric; $\mathrm{Na}^{+}, \mathrm{K}^{+}$in water extract - ion chromatography; $\mathrm{NO}_{3}^{-}, \mathrm{NO}_{2}^{-}, \mathrm{NH}_{4}^{+}$in water extract - photometric; $\mathrm{Li}, \mathrm{Na}, \mathrm{Mg}, \mathrm{Al}, \mathrm{Si}, \mathrm{K}$, $\mathrm{Ca}, \mathrm{Ti}, \mathrm{V}, \mathrm{Cr}, \mathrm{Mn}, \mathrm{Fe}, \mathrm{Co}, \mathrm{Ni}, \mathrm{Cu}, \mathrm{Zn}, \mathrm{As}, \mathrm{Sr}, \mathrm{Cd}, \mathrm{Sn}, \mathrm{Ba}, \mathrm{Pb}-$ atomic emission spectroscopy with inductively coupled plasma with acid-soluble element extraction (the fractions of up to $1 \mathrm{~mm}$ are analysed); 2.3) mineral composition of bottom sediments - in TSU (X-ray phase analysis; the analyst is T.S. Nebera). The details of the analysis are presented in $[6,7]$. 
3. Statistical, landscape, and geochemical analyses of the data obtained are carried out by the authors taking into consideration the results of the previous research [5-7] and requirements [1] in the following sequence: 3.1 ) analysis of river water composition; 3.2) analysis of bottom sediment composition and its relation to hydrochemical and other conditions.

\section{Results and discussion}

3.1 River water. The analysis of hydrochemical data obtained in 2013 and earlier [5-7] showed that river water is fresh with mineralization from very low (up to $0.1 \mathrm{~g} / \mathrm{dm}^{3}$ ) to medium (up to $0.5 \mathrm{~g} / \mathrm{dm}^{3}$ ), hydrocarbonate calcium, from neutral to alkaline (table 1).

Table 1. Water chemical composition of the Aktru and Uznezya Rivers in July August, 2013 and the Tyute River in July, 2014 (distance from the mouth, km)

\begin{tabular}{|c|c|c|c|c|c|c|c|c|c|c|c|}
\hline \multirow[t]{2}{*}{$\begin{array}{l}\text { Para- } \\
\text { meter }\end{array}$} & \multirow{2}{*}{$\begin{array}{c}\text { Aktru } \\
\text { glacier } \\
{[5]}\end{array}$} & \multirow[t]{2}{*}{$\begin{array}{c}\text { Small } \\
\text { rivers } \\
*\end{array}$} & \multicolumn{6}{|c|}{ The Aktru River [7] } & \multicolumn{2}{|c|}{$\begin{array}{c}\text { The } \\
\text { Uznezya } \\
\text { River }\end{array}$} & \multirow{2}{*}{$\begin{array}{c}\text { The } \\
\text { Tyute } \\
\text { River } \\
22.0\end{array}$} \\
\hline & & & 24.5 & 20 & 16.9 & 12.4 & 7.4 & 0.8 & 4.0 & 1.4 & \\
\hline Date & - & - & $\begin{array}{l}19 . \\
07\end{array}$ & $\begin{array}{l}18 . \\
07\end{array}$ & $\begin{array}{l}18 . \\
07\end{array}$ & $\begin{array}{l}18 . \\
07\end{array}$ & $\begin{array}{l}18 . \\
07\end{array}$ & $\begin{array}{c}20 . \\
07\end{array}$ & $\begin{array}{c}06 . \\
08\end{array}$ & $\begin{array}{c}06 . \\
08\end{array}$ & $\begin{array}{c}08 . \\
07\end{array}$ \\
\hline $\begin{array}{c}Q, \\
\mathrm{~m}^{3} / \mathrm{s}\end{array}$ & - & - & 1.3 & 5.2 & 5.3 & 5.3 & 5.4 & 5.8 & - & - & 1.9 \\
\hline $\mathrm{pH}$ & 5.43 & 8.08 & 8.23 & 8.90 & 9.00 & 8.40 & 8.40 & 8.90 & 7.90 & 7.75 & 8.01 \\
\hline \multicolumn{12}{|c|}{$\mathrm{mg} / \mathrm{dm}^{3}$} \\
\hline TDS & 21 & 141 & 63 & 114 & 126 & 153 & 150 & 142 & 188 & 181 & 128 \\
\hline $\mathrm{NO}_{3}^{-}$ & 1.24 & 0.77 & 0.72 & 0.58 & 0.51 & 0.59 & 0.24 & 0.39 & 1.74 & 1.40 & 0.78 \\
\hline $\mathrm{PO}_{4}^{3-}$ & 0.044 & 0.093 & 0.15 & 0.07 & 0.14 & 0.03 & 0.04 & 0.04 & 0.08 & 0.06 & $<0.01$ \\
\hline $\mathrm{Si}$ & 0.46 & 3.78 & 1.78 & 1.18 & 1.57 & 1.06 & 0.77 & 1.48 & 5.77 & 5.15 & 1.02 \\
\hline $\mathrm{Fe}$ & 0.329 & 2.23 & 12.1 & 6.22 & 5.64 & 1.22 & 1.28 & 1.31 & 0.69 & 0.31 & 0.03 \\
\hline DO & 4.72 & 1.60 & $<1.0$ & $<1.0$ & $<1.0$ & $<1.0$ & $<1.0$ & $<1.0$ & $<1.0$ & $<1.0$ & 1.20 \\
\hline \multicolumn{12}{|c|}{$\mathrm{mkg} / \mathrm{dm}^{3}$} \\
\hline $\mathrm{Al}$ & 135 & 1055 & $\begin{array}{c}529 \\
8 \\
\end{array}$ & $\begin{array}{c}250 \\
1 \\
\end{array}$ & $\begin{array}{c}117 \\
8 \\
\end{array}$ & 553 & 153 & 102 & 426 & 395 & 102 \\
\hline $\mathrm{Ti}$ & - & - & 263 & 107 & 40.0 & 17.0 & 3.0 & 0.0 & 11.0 & 10.0 & - \\
\hline $\mathrm{Mn}$ & - & - & 185 & 75.0 & 32.0 & 21.0 & 13.0 & 11.0 & 22.0 & 10.8 & - \\
\hline $\mathrm{Cu}$ & 1.7 & 4.1 & 14.0 & 4.6 & 6.5 & 2.1 & 2.2 & 2.7 & 3.0 & 2.3 & 1.3 \\
\hline $\mathrm{Zn}$ & 44.7 & 14.9 & 37.0 & 16.0 & 18.0 & 15.0 & 5.6 & 12.0 & 8.0 & 8.9 & 15.0 \\
\hline $\mathrm{Cd}$ & 0.33 & 0.06 & 0.20 & 0.10 & 0.10 & 0.10 & $*$ & $*$ & $*$ & $*$ & $*$ \\
\hline $\mathrm{Hg}$ & 0.248 & 0.230 & $*$ & $*$ & 0.36 & 0.28 & $*$ & $\begin{array}{c}0.45 \\
0 \\
\end{array}$ & 0.09 & 0.02 & - \\
\hline $\mathrm{Pb}$ & 0.9 & 2.5 & 11.2 & 2.8 & 2.8 & 0.9 & 0.7 & 1.4 & 1.2 & 0.4 & 0.4 \\
\hline
\end{tabular}

Note: $Q$ - water discharge; DO - dichromate oxidizability; «-» - absence of data or $\mathrm{N}<3$; * materials [5-7] and the data obtained by the authors on the Ursul, Sema, Uznezya, Aktru, Tyute Rivers in 2013-2014; *<0.01 mkg/dm ${ }^{3}$

As compared to glacier water (average content of principle ion sum TDS $21.3 \mathrm{mg} / \mathrm{dm}^{3}$; TDS is calculated as a sum of concentrations of $\mathrm{Ca}^{2+}, \mathrm{Mg}^{2+}, \mathrm{Na}^{+}, \mathrm{K}^{+}, \mathrm{HCO}_{3}{ }^{-}, \mathrm{CO}_{3}{ }^{2-}, \mathrm{SO}_{4}{ }^{2-}$, 
$\mathrm{Cl}^{-}$), water of the Aktru and Tyute Rivers contains high amount of dissolved salts and is characterised by rather a sharp increase in concentrations of several macro- and microelements in glacier zone as a result of melt water interaction with rocks. Downstream in different hydrological conditions one can observe different tendencies in the changes of hydrochemical parameters along the river stream [5-7]. In some cases at the sites of midstream there is a decrease in concentrations (for example, $\mathrm{Al}, \mathrm{Ti}, \mathrm{Mn}, \mathrm{Zn}, \mathrm{Cu}, \mathrm{Pb}$ in water of the Aktru River, table 1) that can be explained by sedimentation of suspended particles, on whose surface the sorption of some elements and low-soluble compounds takes place (carbonates, metal compounds with humic acid) [9]. The effect of surface and ground water inflow with different content of soluble matter is also possible. For example, in the study area of the Katun River basin in Quaternary water-bearing deposits the TDS value amounts $155-297 \mathrm{mg} / \mathrm{dm}^{3}$; in the fracture zone of Lower Cambrian deposits the average value of TDS $-255 \mathrm{mg} / \mathrm{dm}^{3}$, in the fracture zone of Upper- and Middle Cambrian deposits $-329 \mathrm{mg} / \mathrm{dm}^{3}[8]$.

Comparison of the obtained data with the values of maximum permissible concentrations (MPC) adopted in Russia has shown that nearly in all points of study rivers there is an excess of water body quality standards: in fishery and household use - in concentrations of $\mathrm{Fe}$ and $\mathrm{Al}$; fishery - in concentrations of $\mathrm{Mn}, \mathrm{Cu}$. In addition, the violation of water quality standards is found in the Aktru River (mostly in glacier zone) in concentrations of $\mathrm{Ti}, \mathrm{V}, \mathrm{Zn}, \mathrm{Hg}, \mathrm{Pb}$. In authors' opinion, the main reason for MPC excess is a natural factor, i.e. intensive interaction of melt water with rocks and dust. The chemical composition of glaciers is expected to be connected with transport of atmospheric pollutants to some extent, particularly in case of radioactive elements and pesticides. But the key features of river water and sediment chemical composition of study water streams and the whole basin of the $\mathrm{Ob}$ River develop, first of all, under the impact of natural factors [10].

3.2 Bottom sediments. The field survey and study in bottom sediment composition have shown that the largest fractions $(>1 \mathrm{~mm})$ are associated with moraine complexes and river course and floodplain narrowing sites. The increase in the particle diameter within the fraction from 0.01 to $1 \mathrm{~mm}$, is, by contrast, observed along the river length from the source to mouth. The sufficient changes of particle share with the diameter of up to $0.01 \mathrm{~mm}$ are not stated. The composition analysis of water extracts from bottom sediments showed that they are referred to fresh water in terms of mineralization and to hydrocarbonate calcium one in terms of chemical composition. According to $\mathrm{pH}$ values the water extracts are characterized as neutral and weakly alkaline. Total dissolved salts in water extracts of bottom sediments in the Aktru River changes along the river length without profound trends, while in the Uznezya River there is a definite increase in TDS as approaching to the mouth. The consistent DO growth is also recorded in the water extracts of bottom sediments in the Uznezya River as the water surface slopes and current velocity increase. As for the Aktru River, DO value grows rather sharply at the boundary of glacier zone and remains high enough down to the mouth. Probably, it is explained by both soil erosion and intensity of biogeochemical processes at interaction of melt water and mineral particles as well as simultaneous increase in soil erosion and concentration of humic substances in soil (table 2).

The analysis of data on acid-soluble elements has shown that, firstly, in comparison with small and medium valley rivers in Taiga zone of Siberia without anthropogenic pollution [11], in bottom sediments of the Aktru and Uznezya Rivers there is less amount of $\mathrm{K}, \mathrm{Na}, \mathrm{V}, \mathrm{Cr}, \mathrm{Mn}, \mathrm{Al}, \mathrm{Ti}, \mathrm{Si}$ (in Taiga zone of Siberia - the average content of Si - nearly $36 \%$ of sample weight), approximately the same $-\mathrm{Fe}, \mathrm{Co}, \mathrm{Cu}, \mathrm{Zn}, \mathrm{Ni}, \mathrm{Pb}$ and more $-\mathrm{As}$, $\mathrm{Ca}, \mathrm{Mg}$ (table 2). Therefore, one might suggest that there is not always a strong link of 
rather high concentrations of some elements with economic activity impact in the bottom sediments of Western Siberia and Altai.

Table 2. Chemical composition of bottom sediments of the Aktru (18-20.07.2013), Uznezya (06.08.2013) and Tyute Rivers (08.07.2014; distance from the mouth, km)

\begin{tabular}{|c|c|c|c|c|c|c|c|c|c|}
\hline \multirow{2}{*}{$\begin{array}{l}\text { Para- } \\
\text { meter }\end{array}$} & \multirow{2}{*}{$\begin{array}{c}\text { Avera } \\
\text { ge for } \\
\text { Taiga } \\
\text { [11] }\end{array}$} & \multicolumn{6}{|c|}{ the Aktru River } & \multicolumn{2}{|c|}{$\begin{array}{c}\text { the Uznezya } \\
\text { River }\end{array}$} \\
\hline & & 24.5 & 20 & 16.9 & 12.4 & 7.4 & 0.8 & 4.0 & 1.4 \\
\hline $\mathrm{pH}(\mathrm{w})$. & - & 7.76 & 7.68 & 7.76 & 7.68 & 7.68 & 7.66 & 7.35 & 7.72 \\
\hline \multicolumn{10}{|l|}{$\mathrm{mg} / \mathrm{kg}$} \\
\hline TDS(w.) & - & 72.4 & 66.2 & 80.3 & 61.1 & 60.6 & 83.4 & 69.1 & 111.9 \\
\hline $\begin{array}{l}\mathrm{NO}_{3}^{-} \\
\text {(w.) }\end{array}$ & - & 0.70 & 0.22 & 0.45 & 0.26 & 0.28 & 0.12 & 4.78 & 6.11 \\
\hline $\mathrm{DO}(\mathrm{w})$. & - & 2.5 & 65.75 & 64.35 & 66.15 & 64.8 & 72.8 & 2.5 & 25.9 \\
\hline $\mathrm{Na}$ & 8131 & 313 & 315 & 294 & 238 & 290 & 252 & 281 & 422 \\
\hline $\mathrm{Mg}$ & 2768 & 17840 & 8318 & 11200 & 11060 & 10770 & 12380 & 11030 & 9868 \\
\hline $\mathrm{Al}$ & 42271 & 13890 & 9256 & 9543 & 10150 & 11430 & 11360 & 16270 & 26190 \\
\hline $\mathrm{Si}$ & - & 112 & 188 & 105 & 77 & 119 & 74 & 133 & 92 \\
\hline K & 12200 & 2009 & 3598 & 2335 & 2562 & 3513 & 2097 & 1502 & 2764 \\
\hline $\mathrm{Ca}$ & 6563 & 36000 & 27150 & 29800 & 27780 & 24960 & 20380 & 8575 & 10400 \\
\hline $\mathrm{Ti}$ & $\begin{array}{c}4232 . \\
3\end{array}$ & 1413 & 667.3 & 1005 & 907.6 & 688 & 1067 & 679.9 & 390.4 \\
\hline $\mathrm{Mn}$ & 839.7 & 664.9 & 546.0 & 589.0 & 526.2 & 514.8 & 691.0 & 593.3 & 706.5 \\
\hline $\mathrm{Fe}$ & 22548 & 25490 & 15590 & 18970 & 17680 & 17390 & 19250 & 21910 & 20400 \\
\hline $\mathrm{Cu}$ & 22.3 & 29.3 & 15.4 & 18.9 & 10.8 & 12.4 & 16.6 & 14.0 & 15.4 \\
\hline $\mathrm{Zn}$ & 46.9 & 67.3 & 33.2 & 44.5 & 39.7 & 37.7 & 74.6 & 57.8 & 55.7 \\
\hline $\mathrm{Cd}$ & 0.35 & 0.59 & 0.33 & 0.40 & 0.37 & 0.37 & 0.49 & 0.47 & 0.45 \\
\hline $\mathrm{Pb}$ & 9.9 & 9.8 & 4.3 & 5.7 & 3.8 & 4.2 & 12.3 & 5.9 & 7.1 \\
\hline
\end{tabular}

Note: w.e. - water extract; for Tyute river: $\mathrm{pH}(\mathrm{w})=$.7.6 ; TDS(w.) $=130.4 \mathrm{mg} / \mathrm{kg} ; \mathrm{NO}_{3}{ }^{-}$ (w.) $=0.05 \mathrm{mg} / \mathrm{kg}$

Secondly, in the Aktru River the maximum concentrations of most study elements are found in the bottom sediments of the glacier zone $(24.5 \mathrm{and} / \mathrm{or} 20 \mathrm{~km}$ from the mouth); approximately the same content or definite decrease from source to mouth in the Aktru River, $\mathrm{Ca}, \mathrm{Fe}, \mathrm{Mn}, \mathrm{Na}$ are revealed; in the Uznezya River the increase in $\mathrm{Si}, \mathrm{Fe}, \mathrm{Co}$, As is observed from the sources to the mouth (table 2).

Thirdly, the statistically significant relationships of river water concentrations and bottom sediments (at correlation coefficient $r$ more than double error of its determination) are found for $\mathrm{Cu}(r=0.97 \pm 0.10), \mathrm{Fe}(r=0.71 \pm 0.22)$, Ti $(r=0.63 \pm 0.27), \mathrm{NO}_{3}{ }^{-}(r=$ $0.59 \pm 0.29)$, but taking into account a few number of samples the conclusion on relationship of water geochemical parameters and bottom sediments of small mountain rivers are still indicative. In terms of $\mathrm{pH}, \mathrm{TDS}, \mathrm{DO}, \mathrm{Pb}, \mathrm{Cd}, \mathrm{Mn}, \mathrm{Al}, \mathrm{Si}$ the statistically significant relationships were not stated.

Fourthly, there is a weak link of geochemical parameters with mineralogical composition of bottom sediments and it is observed only in the fraction with the particle diameter of up to $0.01 \mathrm{~mm}$. Particularly, a notable reduction of albite is established in the 
sample taken $0.8 \mathrm{~km}$ up the mouth of the Aktru River, as compared to the rest five samples (in the middle part of the fraction $<0.01$ of approximately $10-15 \%$ of its weight, the following minerals are revealed in the mouth section, $\mathrm{km}: 24.5 \mathrm{~km}$ - clinochlore, albite, calcite; $20 \mathrm{~km}$ - chlorite, albite; $16.9 \mathrm{~km}$ - chlorite, albite; $12.4 \mathrm{~km}$ - mica, kaolinite, albite, calcite; $7.4 \mathrm{~km}$ - mica, kaolinite, albite, calcite; $0.8 \mathrm{~km}$ - chlorite, mica. To some extent, this fact is correlated with the trend towards reduction of sodium concentration in the bottom sediments from the source to the mouth (table 2). In other cases any relationship between mineral and chemical composition of bottom sediments is not revealed in the Aktru River (in all fractions of the particle diameter from 0.01 to $1 \mathrm{~mm}$ quartz and plagioclase are revealed and, almost in all samples - potassic feldspar, mica, calcite, chlorite, and kaolinite).

Fifthly, the most significant inverse dependencies of geochemical parameters of the bottom sediments in the Aktru and Tyute Rivers are established for acid-soluble $\mathrm{Mg}, \mathrm{Al}$, $\mathrm{Ca}, \mathrm{Ti}, \mathrm{Fe}, \mathrm{Cu}, \mathrm{Cd}$ on water discharge at the time of study. However, these links are generally weak (one can observe an excessively wide spread of points with their small amount). A more stable link is the relationship of some element concentrations in bottom sediments and the part of glaciers in the general catchment area. This parameter is also an indirect characteristic of water exchange that reflects, first of all, the area of water interaction with rocks. Thus, there is the relationship $S_{\mathrm{Ca}}=11907.94 \cdot\left(100 \cdot A_{g} / A_{b}\right)^{0.26}$ of calcium concentration $S_{\mathrm{Ca}}$ in the bottom sediments of the Aktru River, where $A_{b}$ and $A_{g}-$ catchment and glacier areas (at the cross-section); the square of correlation ratio $R^{2}=0.76$.

Quality standards of bottom sediments have not been stated in Russia. However, if one suggests that bottom sediments are responsible for soil cover development of the river flood plains, it is possible to compare the geochemical parameters of bottom sediments with soil standard values. As for the Aktru and Uznezya Rivers such a comparison has shown that floodplain soil with similar chemical composition do not correlate with standards of $\mathrm{Cr}$, $\mathrm{Mn}, \mathrm{Co}, \mathrm{Ni}, \mathrm{Cu}, \mathrm{Zn}, \mathrm{As}, \mathrm{Cd}, \mathrm{Pb}$ concentrations. As is the case of river water, this fact is mostly explained by natural factors, first of all, composition of underlying and waterbearing rocks and water exchange rate defining, based on $[9,12]$, time and interaction area in "water - rock" system.

\section{Conclusion}

Chemical composition of bottom sediments in the Aktru, Tyute and Uznezya Rivers is characterized by concentrations of $\mathrm{Fe}, \mathrm{Co}, \mathrm{Cu}, \mathrm{Zn}, \mathrm{Pb}$ typical for valley rivers of Siberian Taiga zone. At the same time, the bottom sediments of study rivers contain less amount of $\mathrm{K}, \mathrm{Na}, \mathrm{V}, \mathrm{Cr}, \mathrm{Mn}, \mathrm{Al}, \mathrm{Ti}, \mathrm{Si}$ and more - As, Ca, Mg. As a first approximation, one could suggest that there is a sharp increase in relative parts of $\mathrm{Al}, \mathrm{Na}, \mathrm{K}$ and, particularly, Si from mountain to valley regions due to both accumulation of weathering products of primary aluminosilicates in the sediments and washout of $\mathrm{Ca}$ and $\mathrm{Mg}$ from them at solution of carbonate minerals.

Transformation of chemical composition of bottom sediments is a non-linear process and depends on both composition of underlying and water-bearing rocks and water exchange rate that regulates time, conditions, and stages of interactions in "water - organic matter - rock" system (features of water exchange are not only water discharge or water flow module, but also relationship of some hydromorphological parameters). As for the Aktru River it is expressed in maximum concentrations of most study elements in the glacier zone of catchment area, where the main part of water flow develops and the initial contact of melting ice with rocks occurs.

Along the water flow one can observe decrease in their concentrations and subsequent fluctuations that are weakly connected with mineral composition of bottom sediments. 
Presumably, it is due to prevalence of longitudinal advective transport of suspended and bed load of a mountain river as compared to the other parts of the turbulent diffusion equation. Definite relationship between chemical and mineral compositions is established only for albite, whose decrease in the fraction of diameter less than $0.01 \mathrm{~mm}$ is correlated with the general sodium reduction from the source to the mouth.

\section{Acknowledgements}

The research has been supported by the grant issued in accordance with VIU_VAF_144_2014.

\section{References}

1. A.A. Golovin, N.N.Moskalenko et al. Requirements for production and results of multipurpose geochemical mapping of 1: 200000 scale . Moscow. IMGRE Publishing House, 92 (2002) [in Russian]

2. D.P.Loucks and E. Van Beek. Water resources systems planning and management. An Introduction to Methods, Models and Applications. Turin, UNESCO PH, 680 (2005)

3. Water Quality Assessments - A Guide to Use of Biota, Sediments and Water in Environmental Monitoring. London, Chapman \& Hall, 348 (1996)

4. Yu.K. Narozhny, S.A. Nikitin, A.A. Lukianov and A.B. Osipov. Mountain-glacier basin of the Aktru River: new morphometric and resource characteristics. Voprosy Geograpgii Sibiri. Volume 26, pp 67-74 (2006) [in Russian]

5. O.G. Savichev and V.V. Paromov. Chemical composition of glacial meltwaters and river waters within the Aktru river basin (Gornyi Altai) Geography and Natural Resources. Volume 4, pp 364-370 (2013)

6. O.G. Savichev, V.V. Paromov, Yu.G. Kopylova, A.A. Khvashchevskaya and N.V. Guseva. Ecogeochemical condition of surface waters in Katun River basin (Gorny Altai). TSU J., Volume 366, pp 157-161 (2013) [in Russian]

7. V.V. Paromov, O.G. Savichev, L.N. Shantikova and Ks.A. Torgasheva. Ionic runoff and chemical composition of glacial waters of the Aktru river (Gorny Altai). TSU J, Volume 383, pp 226-231 (2014) [in Russian]

8. S.L. Shvartsev, V.S. Kuskovsky, O.G. Savichev, A.A. Lukin and Ye.V. Domrocheva. On criteria of distinguishing the earlier stages of groundwater anthropogenic pollution (by the example of the Katun River basin). Proceedings of Tolstikhin's readings. pp 90-95 (1999) [in Russian]

9. O.G. Savichev. Influence of the interactions within the water - earth materials system on the formation of river water composition in the Ob basin Geography and Nat Res. Volume 30. Issue 2, pp 161-166 (2009)

10. O.G. Savichev, A.K. Mazurov, I.I. Pipko, V.I. Sergienko and I.P. Semiletov. Spatial Patterns of the Evolution of the Chemical Composition and Discharge of River Water in the Ob River Basin Doklady Earth Sciences . Volume 466, pp 47-51. (2016). DOI: 10.1134/S1028334X16010141

11. O.G. Savichev and P.T. Duong. Zone laws of change of chemical composition of river sediments of Siberia and condition of its formation Bulletin of the Tomsk Polytec Univ. Volume 323, Issue 1, pp 157-161 (2013) [in Russian]

12. M. Meybeck. Global chemical weathering of surficial rocks estimated from river dissolved loads Am. J. of Sci. Volume 287, Issue 5, pp 401-428 (1987). 